\title{
Pengaruh Pembelajaran Matematika Al-Qur'an dengan Model Pembelajaran Kooperatif Tipe Think Pair Share Terhadap Kemampuan Komunikasi Matematis Siswa
}

\author{
Syafi'i Muhamad Subhi ${ }^{1, a)}$, Indah Nursuprianah ${ }^{2, \text { b) }}$, Nurma Izzati ${ }^{2, c)}$ \\ ${ }^{1}$ Jurusan Tadris Matematika IAIN Syekh Nurjati Cirebon \\ ${ }^{2}$ Jurusan Tadris Matematika IAIN Syekh Nurjati Cirebon
}

Email: ${ }^{\text {a) }}$ syafiimuhamadsubhi@ @yekhnurjati.ac.id, ${ }^{\text {b) indahnursuprianah @ gmail.com, }}{ }^{\text {c) }}$ nurma@ syekhnurjati.ac.id.

\begin{abstract}
The purpose of this research was to know: (1) students' responses to the learning of al-qur'an mathematics with cooperative learning models think pair share type; (2) mathematical communication skills of students taught by learning al-quran mathematics with cooperative learning models think pair share type; (3) the effect of learning al-quran mathematics with think pair share type cooperative learning models on students' mathematical communication skills. This research method is an experimental method with a quantitative approach and research design is the posttest-only control design. The population in this study was VII grade students of MTsNU Astanajapura Cirebon. Sampling is done by simple random sampling technique. The instruments used in the study were questionnaires and tests. The results of the study are for students' responses to learning mathematics al-quran with the cooperative learning model of the type of think pair share obtained an average percentage of $75.11 \%$ (26 students) who responded positively. For the average value of students' mathematical communication skills obtained a percentage of $77.79 \%$ so that it can be said to be good. Hypothesis test results in this study using the $t$ test ( $t$ accent) obtained $t$-count $>t$-table $(34,365>-1,706)$ so that the hypothesis is accepted that there is an influence on the learning of the mathematics of the qur'an with cooperative learning models think pair share type on students' mathematical communication skills.
\end{abstract}

Keywords: Mathematics Learning, Al-Qur'an, Think Pair Share, Mathematical Communication.

\begin{abstract}
Abstrak
Tujuan dalam penelitian ini adalah untuk mengetahui: (1) respon siswa terhadap pembelajaran matematika al-qur'an dengan model pembelajaran kooperatif tipe think pair share; (2) kemampuan komunikasi matematis siswa yang diajarkan dengan pembelajaran matematika al-qur'an dengan model pembelajaran kooperatif tipe think pair share; (3) pengaruh pembelajaran matematika al-qur'an dengan model pembelajaran kooperatif tipe think pair share terhadap kemampuan komunikasi matematis siswa. Metode penelitian ini adalah metode eksperimen dengan pendekatan kuantitatif dan desain penelitian adalah the posttest-only control design. Populasi dalam penelitian ini adalah siswa kelas VII MTsNU Astanajapura Cirebon. Pengambilan sampel yang dilakukan dengan teknik simple random sampling. Instrumen yang digunakan dalam penelitian adalah angket dan tes. Hasil penelitian yaitu untuk respon siswa terhadap pembelajaran matematika al-qur'an dengan model pembelajaran kooperatif tipe think pair share ini didapat persentase rata-rata $75,11 \%$ (26 siswa) yang merespon positif. Untuk nilai rata-rata dari kemampuan komunikasi matematis siswa diperoleh persentase sebesar 77,79\% sehingga bisa dikatakan baik. Hasil uji hipotesis dalam penelitian ini dengan menggunakan uji t' ( $\mathrm{t}$ aksen) didapat t-hitung > t-tabel (34,365 > 1,706) sehingga hipotesis diterima bahwa terdapat pengaruh pembelajaran matematika al-qur'an dengan model pembelajaran kooperatif tipe think pair share terhadap kemampuan komunikasi matematis siswa.
\end{abstract}

Kata-kata kunci: Pembelajaran Matematika, Al-Qur'an, Think Pair Share, Komunikasi Matematis. 


\section{PENDAHULUAN}

Matematika adalah pola pikir, pola mengorganisasikan, pembuktian yang logis. Matematika merupakan bahasa yang menggunakan istilah yang mendefinisikan dengan cermat, jelas, dan akurat, representasinya dengan simbol dan padat, lebih berupa bahasa simbol mengenai ide dari pada mengenai bunyi (Suherman, 2013).

Matematika merupakan mata pelajaran yang wajib pada jenjang pendidikan di Indonesia dari tingkat sekolah dasar hingga perguruan tinggi, materi dan bahan ajarnya disesuaikan dengan tahap perkembangan dan pertumbuhan peserta didik. Dalam perkembangan ilmu pengetahuan yang dewasa ini, matematika bisa dikatakan sebagai dasar dari berbagai ilmu pengetahuan.

Menurut Nursuprianah (2017) bahwa AlQur'an adalah firman Allah SWT. Kitab suci yang mengandung pesan samawi yang diperantarai oleh wahyu dan isyarat yang cepat yang bersifat rahasia disampaikan oleh Allah kepada Nabi dan Rosul yang menjadi mukjizat yang diturunkan kepada Nabi Muhammad SAW. Ilmu Pengetahuan (sains) termasuk matematika sudah ada sejak zaman Nabi Adam as, bahkan Nabi Adam as adalah bapak sains dalam peradaban umat islam dan memperkenalkan teknologi. Pada zaman Nabi Adam as telah ditemukan sektor pertanian dan peternakan. Habil seorang peternak (ra'iyan), sedangkan Qabil seorang petani (harrathan) (Maksudin, 2015). Masih banyak lagi didalam AlQur'an yang menceritakan nabi-nabi Allah SWT yang dikaitkan dengan ilmu pengetahuan (sains). Misalnya pada zaman nabi Syu'ayb telah ada alat (teknologi) timbangan, dan lainnya.

Beberapa contoh diatas, menjelaskan bahwa ilmu pengetahuan (sains) dan Al-Qur'an itu saling bersanding, dan apapun yang ada didunia termasuk ilmu sosial, humaniora, matematika, metafisika dan semuanya terhimpun menjadi sains yang bersumber pada Al-Qur'an.

Berbicara tentang sains, sudah jelas bahwa matematika termasuk dalam sains yang telah diceritakan diatas termasuk bagian dari AlQur'an, sehingga matematika bersumber dalam Al-Qur'an. Hal ini dapat dilihat bahwa Al-Qur'an terdiri atas bahasa verbal (tulisan) dan juga bahasa numerik (angka) yang keduanya merupakan bahasa simbol, dimana huruf mewakili bahasa bunyi dan angka mewakili bahasa bilangan, apa yang dilakukan anak-anak atau orang dewasa pada saat belajar membaca, mempelajari, dan memahami Al-Qur'an mereka diberi pemahaman tentang adanya angka atau bilangan, salah satunya dengan penekanan atau pengalaman (Fathoni, 2012).

Sejarah menunjukan bahwa matematika sangat dibutuhkan manusia, matematika tidak dapat dipisahkan dari kehidupan sehari-hari. Begitu juga tanpa matematika, manusia tidak dapat membuat tempat untuk berteduh, tidak dapat membuat alat komunikasi, tidak bisa membuat alat transportasi dan sebagainya. Sehingga dalam hal pendidikan memadukan matematika dengan Al-Qur'an sangat efektif untuk digunakan.

Belakangan ini masih ada beberapa orang yang tidak mengetahui bahwa Al-Qur'an merupakan kalam Allah yang juga berbicara tentang prinsipprinsip dasar matematika, misalnya mengenai konsep himpunan, konsep bilangan, konsep statistik semuanya ada dalam Al-Qur'an. Dan masih ada beberapa orang yang tidak menyukai matematika, bahkan ada yang menganggap tidak penting, setidaknya ada 3 faktor penyebabnya (Abdussyakir, 2007) yaitu: pertama adanya anggapan bahwa matematika dikembangkan oleh non-muslim, hal ini menyebabkan gaung perkembangan matematika lebih keras terdengar dari dunia barat yang mayoritas non-muslim. Sedangkan tidak mengetahui bahwa sebenarnya islam adalah pelopor pengembangan sains terlebih dahulu. Adapun faktor yang kedua adalah sebagian umat islam tidak mengetahui bahwa AlQur'an banyak berbicara tentang matematika. Serta faktor yang ketiga adalah umat islam menyalah artikan pendapat imam Al-Ghozali tentang mempelajari ilmu umum adalah fardlu kifayah, sehingga menyebabkan mereka menyampingkan ilmu umum. Karena merebaknya paradigma tersebut, sehingga menyebabkan kemunduran bagi umat islam dibidang sains termasuk matematika. Hal ini dapat dilihat dari rendahnya hasil belajar matematika siswa. Dan terkadang masih banyak siswa yang merasa matematika tidak terlalu menarik untuk dipelajari, bahkan ada yang merasa takut dengan matematika. Bahkan ada yang menyebutkan bahwa berbagai pendapat yang muncul mengenai matematika merupakan hasil dari pengetahuan dan pengalaman yang berbeda dari masingmasing matematikawan (Nursuprianah, 2017).

Tujuan pembelajaran Matematika dari NCTM dan kurikulum 2013 sudah selaras, tetapi dalam pelaksanaannya masih belum maksimal akibatnya hasil yang diharapkan dari tujuan tersebut belum tercapai dengan yang diharapkan, dengan 
rendahnya prestasi belajar matematika siswa Indonesia di taraf International. Dari tujuan pembelajaran matematika diatas juga, terlihat bahwa salah satu aspek yang ditekankan dalam kurikulum 2013 dan NCTM adalah meningkatkan kemampuan komunikasi matematis siswa.

Komunikasi matematis merupakan hal yang sangat penting dimiliki oleh siswa. Sesuai dengan yang terdapat dalam National Council of Teachers of Mathematics (NCTM, 2000) dijelaskan bahwa komunikasi adalah suatu bagian esensial dari matematika dan pendidikan matematika. Pendapat ini mengisyaratkan pentingnya komunikasi dalam pemebelajaran matematika. Menurut Izzati (2014) mengemukakan bahwa kemampuan komunikasi matematis merupakan kemampuan dalam menyampaikan gagasan/ide matematis, baik secara lisan maupun tulisan serta kemampuan memahami dan menerima gagasan/ide matematis orang lain secara cermat, analitis, kritis, dan evaluatif untuk mempertajam pemahaman. Melalui komunikasi, siswa dapat menyampaikan ide-idenya kepada guru dan kepada siswa lainnya. Hal ini berarti kemampuan komunikasi matematis siswa harus lebih ditingkatkan.

Disamping pentingnya kemampuan komunikasi matematis, juga diperlukan sikap yang harus dimiliki oleh seorang siswa salah satunya adalah semangat belajar. Dengan sikap yang demikian, siswa diharapkan dapat terus mengembangkan kemampuan matematika serta dapat menggunakan matematika untuk menyelesaikan masalah-masalah yang dihadapi dalam hidupnya.

Berdasarkan hasil penelitian pendahuluan yang dilakukan peneliti di MTsNU Astanajapura Cirebon telah menemukan dan mewawancarai dengan beberapa siswa bahwa matematika itu sangat sulit bagi mereka, hal ini juga dikarenakan kurangnya metode atau model pembelajaran yang digunakan guru yang justru hanya menerapkan metode konvensional saja sehingga hasil belajar kurang maksimal serta butuh dukungan guru yang paham dengan hal ini. Peneliti juga menyaksikan siswa masih kurang berani untuk mengkomunikasikan didepan kelas dalam proses pembelajaran.

Pembelajaran sangat bergantung pada kemampuan guru dalam melaksanakan proses pembelajaran. Pembelajaran yang bersangkutan dengan matematika tidak dapat digeneralisasikan. Ini berarti metode yang digunakan dalam pembelajaran matematika harus sesuai dengan kepada siapa materi itu diajarkan. Pada pembelajaran matematika harus secara aktif mengkreasikan kembali pengetahuan yang ingin dimilikinya (Izzati, 2017). Oleh karena itu, perlu dilakukan pembelajaran yang bermakna, yang dapat merubah paradigma mereka terhadap matematika. Pembelajaran yang bermakna ini salah satunya adalah menerapkan model pembelajaran kooperatif tipe think pair share, karena model pembelajaran ini menyajikan pembelajaran berfikir, berpasangan, dan berbagi sangat cocok untuk meningkatkan kemampuan komunikasi matematis siswa. Dengan menggunakan model pembelajaran yang bermakna ini, siswa akan mengetahui matematika mempunyai arti penting bagi dirinya.

Berdasarkan penjelasan diatas, maka peneliti ingin menawarkan sebuah ide bagaimana pengaruh pembelajaran matematika al-qur'an dengan model pembelajaran kooperatif tipe think pair share terhadap kemampuan komunikasi matematis siswa. Dengan cara ini yang digunakan dalam proses belajar mengajar untuk menghubungkan Matematika dengan Al-Qur'an. Sehingga peserta didik mengetahui bahwa semua ilmu yang ada didunia berkaitan dengan AlQur'an.

Adapun Tujuan dalam penelitian ini adalah untuk mengetahui: (1) respon siswa terhadap pembelajaran matematika al-qur'an dengan model pembelajaran kooperatif tipe think pair share; (2) kemampuan komunikasi matematis siswa yang diajarkan dengan pembelajaran matematika alqur'an dengan model pembelajaran kooperatif tipe think pair share; (3) pengaruh pembelajaran matematika al-qur' an dengan model pembelajaran kooperatif tipe think pair share terhadap kemampuan komunikasi matematis siswa.

\section{METODE}

Metode penelitian yang digunakan dalam penelitian ini adalah metode eksperimen. Jenis penelitian eksperimen adalah suatu penelitian yang digunakan untuk mencari pengaruh perlakuan tertentu terhadap perlakuan yang lainnya dalam kondisi terkendalikan (Sugiyono, 2016). Pendekatan yang digunakan pada penelitian ini yaitu pendekatan kuantitatif. Pendekatan kuantitatif dapat diartikan sebagai penelitian yang digunakan untuk meneliti populasi dan sampel tertentu, teknik pengambilan sampel berupa random, pengumpulan datanya merupakan instrumen penelitian, analisis datanya bersifat kuantitatif atau statistika dengan tujuan menguji 
hipotesis yang telah ditetapkan (Sugiyono, 2018). Desain penelitian adalah keseluruhan dari perencanaan untuk menjawab pertanyaan penelitian dan mengantisipasi beberapa kesulitan yang mungkin timbul selama proses penelitian (Lestari \& Yudhanegara, 2017). Hal ini penting karena desain penelitian merupakan strategi untuk mendapatkan data yang dibutuhkan untuk keperluan pengujian hipotesis atau untuk menjawab pertanyaan penelitian, dan sebagai alat untuk mengontrol variabel yang berpengaruh daalm penelitian (Sugiyono, 2016). Maka desain dalam penelitian ini adalah the posttest-only control design. Pada penelitian ini ada dua kelompok subjek penelitian yaitu kelompok eksperimen dan kelompok kontrol. Kelompok eksperimen mendapatkan perlakuan dengan pembelajaran matematika al-qur'an dengan model pembelajaran think pair share dan kelompok kontrol dengan perlakuan metode konvensional. Kedua kelompok diberikan tes akhir dengan instrumen tes yang sama.

Populasi merupakan keseluruhan objek dan subjek yang memiliki karakteristik tertentu berdasarkan pada apa yang telah ditetapkan oleh peneliti guna diuji dan ditarik kesimpulan (Sugiyono, 2016). Selain itu juga, Populasi adalah wilayah generalisasi yang terdiri atas objek/subjek yang memiliki kuantitas dan karakteristik tertentu yang ditetapkan oleh peneliti untuk dipelajari dan kemudian ditarik kesimpulannya (Riduwan, 2011). Populasi dalam penelitian ini adalah siswa kelas VII MTsNU Astanajapura, Cirebon tahun ajaran 2019/2020. Penelitian ini bermaksud untuk memberikan perlakuan pada sampel, selanjutnya peneliti ingin mengetahui efek atau pengaruh dari hasil perlakuan tersebut. Perlakuan yang dimaksud adalah pembelajaran matematika alqur'an dengan model pembelajaran think pair share pada kelas eksperimen dan metode konvensional pada kelas kontrol.

Sedangkan menurut Arikunto (2018), Sampel dapat diartikan sebagai objek yang difokuskan peneliti dalam melakukan penelitian. Sampel yang baik adalah sampel yang dapat mewakili populasi dalam aspek tertentu yang sedang dipelajari. Teknik pengambilan sampel dalam penelitian ini menggunakan teknik simple random sampling, karena setiap individu pada kelas homogen sehingga dapat diambil dari individu pada kelas manapun (Mulyatiningsih, 2014).

Instrumen Penelitian menurut Sugiyono (2016, hal. 148) merupakan alat bantu untuk mengukur fenomena alam dan sosial yang diamati. Secara specifik semua fenomena ini disebut variabel penelitian. Sedangkan menurut Lestari \& Yudhanegara (2017, hal. 163) instrumen adalah suatu alat yang digunakan untuk mengumpulkan data dalam suatu penelitian. Instrumen pengumpulan data yang digunakan dalam penelitian ini adalah angket respon siswa dan tes kemampuan komunikasi matematis yang berbentuk uraian sebanyak 10 soal. Sebelum digunakannya tes alat pengumpulan data tersebut telah divalidasi ahli, validasi empiris, menghitung reliabilitas, menghitung indeks kesukaran dan daya pembeda.

Dari penelitian yang diperoleh data kuantitatif. Data kuantitatif didapatkan dari tes kemampuan komunikasi matematis. Pengolahan data kuantitatif dilakukan melalui dua tahap utama. Tahap pertama: menguji persyaratan statistik yang diperlukan sebagai dasar dalam pengambilan hipotesis, yaitu uji normalitas sebaran data subyek sampel dan uji homogenitas varians. Tahap kedua: menguji ada atau tidaknya perbedaan atau pengaruh dari masing-masing kelompok dengan menggunakan uji t' ( $\mathrm{t}$ aksen) karena data tak homogen.

Uji prasyarat untuk pengujian penelitian ini meliputi uji normalitas dan uji homogenitas.

Uji Normalitas

Uji Normalitas merupakan salah satu uji prasyarat untuk memenuhi asumsi kenormalan dalam analisis data statistik parametrik. Pengujian ini dapat digunakan untuk mengetahui apakah sebaran data yang diperoleh berdistribusi normal atau tidak (Lestari \& Yudhanegara, 2017). Tujuan dilakukan uji normalitas adalah untuk menguji apakah data yang diperoleh berasal dari populasi berdistribusi normal atau tidak maka digunakan uji normalitas. Uji normalitas dalam penelitian ini menggunakan uji Shapiro-Wilk dengan bantuan software SPSS version 25 dengan prosedur sebagai berikut:

Pengambilan Hipotesis

$H_{0}=$ data berdistribusi normal

$H_{1}=$ data tidak berdistribusi normal

dengan kriteria pengujian hipotesis sebagai berikut:

Jika nilai /P-value/ Sig. $>0,05$, maka $H_{0}$ diterima.

Jika nilai /P-value/ Sig. $\leq 0,05$, maka $H_{0}$ ditolak.

Uji Homogenitas

Uji homogenitas dilakukan untuk mengetahui apakah variansi atau keberagaman nilai yang sama secara statistik data dari sampel yang dianalisis homogen atau tidak, (Lestari \& Yudhanegara, 2017, hal. 248). Jika ternyata keduanya 
berdistribusi normal, dilanjutkan dengan uji homogenitas. Uji homogenitas dalam penelitian ini menggunakan uji Levene Statistic dengan bantuan software SPSS version 25 dengan prosedur sebagai berikut:

Pengambilan Hipotesis

$H_{0}=$ kedua varians homogen

$H_{1}=$ kedua varians tidak homogen

dengan kriteria pengujian hipotesis berikut:

Jika nilai /P-value/ Sig. > 0,05, maka $H_{0}$ diterima, yaitu berdistribusi homogen.

Jika nilai /P-value/ Sig. $\leq 0,05$, maka $H_{0}$ ditolak, yaitu berdistribusi tidak homogen.

Uji t' (t aksen)

Uji $t$ test untuk dua sampel independen digunakan untuk menguji hipotesis mengenai dua rata-rata atau dua proporsi dari dua sampel independen pada suatu populasi (Lestari \& Yudhanegara, 2017). jika suatu data berdistribusi normal, namun nilai varians kedua data tidak homogen, maka untuk menguji hipotesis uji $t$ independent tidak digunakan, maka diganti uji hipotesis tersebut dengan menggunakan uji t' $(t$ Aksen). Jika terdapat perbedaan yang sangat signifikan antara kelompok kelas eksperimen dan

\section{HASIL DAN PEMBAHASAN}

Penelitian ini dilaksanakan di MTsNU Astanajapura Cirebon, peneliti mengambil dua kelas untuk dijadikan kelompok penelitian. Pada saat proses pembelajarannya, kedua kelompok tersebut diberikan perlakuan yang berbeda. Sampel yang digunakan sebanyak 52 siswa yang terdiri dari kelas eksperimen pada kelas VII A dengan jumlah siswa 26 orang yang diberikan pembelajaran matematika al-qur'an dengan model pembelajaran kooperatif tipe think pair share, sedangkan kelas kontrol pada kelas VII B dengan jumlah siswa 26 orang yang diberikan pembelajaran metode konvensional. Materi yang diajarkan pada kedua kelas adalah Garis dan Sudut.

Pada akhir pembelajaran kedua kelompok tersebut diberikan posttest berupa tes uraian atau essay yang terdiri dari 10 soal yang digunakan untuk mengetahui bagaimana kemampuan komunikasi matematis siswa dan mencari tahu apakah terdapat pengaruh pembelajaran matematika al-qur'an dengan model pembelajaran kelas kontrol, maka perlakuan yang diberikan pembelajaran tersebut berpengaruh positif.

Adapun pengujian ini dilakukan dengan bantuan Software Microsoft Excel dengan prosedur sebagai berikut:

Adapun perumusan hipotesis pengujian tersebut berlaku ketentuan sebagai berikut:

$H_{0}: \mu_{1}=\mu_{2}$ tidak terdapat perbedaan rata-rata kemampuan komunikasi matematis siswa pada kelas eksperimen dibandingkan dengan siswa pada kelas kontrol.

$H_{1}: \mu_{1} \neq \mu_{2}$ terdapat perbedaan rata-rata kemampuan komunikasi matematis siswa pada kelas eksperimen dan siswa pada kelas kontrol.

Keterangan:

$\mu_{1}=$ skor rata-rata hasil tes kemampuan komunikasi matematis siswa pada kelas eksperimen

$\mu_{2}=$ skor rata-rata hasil tes kemampuan komunikasi matematis siswa pada kelas kontrol

dengan kriteria pengujian hipotesis sebagai berikut:

Jika nilai $t_{\text {hitung }}<t_{\text {tabel }}$, maka $H_{0}$ diterima artinya tidak terdapat perbedaan antara $\mu_{1}$ dan $\mu_{2}$

Jika nilai $t_{\text {hitung }}>t_{\text {tabel }}$, maka $H_{0}$ ditolak artinya terdapat perbedaan antara $\mu_{1}$ dan $\mu_{2}$.

kooperatif tipe think pair share terhadap kemampuan komunikasi matematis siswa. Dan untuk kelas eksperimen akan diberikan angket respon siswa setelah diberikan perlakuan pembelajaran matematika al-qur'an dengan model pembelajaran kooperatif tipe think pair share guna mempertimbangkan hasil dari posttest yang diberikan.

Untuk mengetahui respon siswa terhadap penerapan pembelajaran matematika al-qur'an dengan model pembelajaran kooperatif tipe think pair share pada kelas eksperimen dibagikan angket respon yang berupa pernyataan dengan terdiri dari 12 indikator dan 30 pernyataan serta 4 alternatif pilihan jawaban (Sangat Setuju, Setuju, Tidak Setuju, Sangat Tidak Setuju). Untuk lebih jelasnya semua hasil data perolehan dari tiap indikator jawaban angket respon siswa terhadap pembelajaran matematika al-qur'an dengan model pembelajaran kooperatif tipe think pair share dapat disajikan pada Tabel 1 sebagai berikut:

Tabel 1 Rekapitulasi Hasil Angket Respon Siswa

\begin{tabular}{|c|c|c|c|}
\hline No. & Indikator & Persentase & Kriteria \\
\hline
\end{tabular}




\begin{tabular}{|c|c|c|c|}
\hline 1 & Menjadikan pengetahuan yang bermakna dan relevan & $77,88 \%$ & Kuat \\
\hline 2 & Memotivasi siswa untuk lebih semangat belajar & $64,66 \%$ & Kuat \\
\hline 3 & Menyegarkan kembali pengetahuan siswa & $63,46 \%$ & Kuat \\
\hline 4 & Menyajikan materi secara singkat & $79,81 \%$ & Kuat \\
\hline 5 & Mengamati aktivitas siswa dalam kelompok & $74,04 \%$ & Kuat \\
\hline 6 & Komunikasi dua arah & $76,92 \%$ & Kuat \\
\hline 7 & Keunggulan belajar dalam berpasangan & Kuat \\
\hline 8 & $\begin{array}{c}\text { Memberikan kesempatan siswa untuk berfikir materi dan jawaban atas } \\
\text { permasalahan yang diberikan guru }(\text { think })\end{array}$ & $75,96 \%$ & Kuat \\
\hline 10 & Memberikan kesempatan kepada siswa untuk mendiskusikan hasil \\
\hline 11 & Memaban dengan pasangannya (pair) & $75 \%$ & Kuat \\
\hline
\end{tabular}

Berdasarkan Tabel 1 menunjukan bahwa hasil angket respon siswa terhadap pembelajaran matematika Al-Qur'an dengan model pembelajaran kooperatif tipe think pair share dari setiap indikatornya. Dari tabel tersebut terlihat bahwa respon siswa pada kelas eksperimen sangat positif dengan persentase tiap indikator berikut menjadikan pengetahuan yang bermakna dan relevan memperoleh hasil persentase $77,88 \%$, Indikator memotivasi siswa untuk lebih semangat belajar memperoleh hasil persentase $64,66 \%$, Indikator menyegarkan kembali pengetahuan siswa memperoleh hasil persentase $63,46 \%$, Indikator menyajikan materi secara singkat memperoleh hasil persentase $79,81 \%$, Indikator mengamati aktivitas siswa dalam kelompok memperoleh hasil persentase $74,04 \%$, Indikator komunikasi dua arah memperoleh hasil persentase $76,92 \%$, Indikator keunggulan belajar dalam berpasangan memperoleh hasil persentase $75,96 \%$, Indikator tahap think memperoleh hasil persentase $78,85 \%$, Indikator tahap pair memperoleh hasil persentase $75,32 \%$, Indikator tahap share memperoleh hasil persentase $71,79 \%$, Indikator evaluasi kinerja dalam kelompok berpasangan memperoleh hasil persentase 78,53\% serta indikator memberikan penghargaan kepada individu atau kelompok memperoleh hasil persentase $84,13 \%$ dengan rata-rata seluruh persentase indikatornya sebesar $75,11 \%$ maka kategori kuat.

Selain itu juga, rekapitulasi hasil persentase angket respon siswa terhadap pembelajaran matematika Al-Qur'an dengan model pembelajaran kooperatif tipe Think Pair Share dari tiap indikatornya dapat disajikan pada Gambar 1 sebagai berikut: 


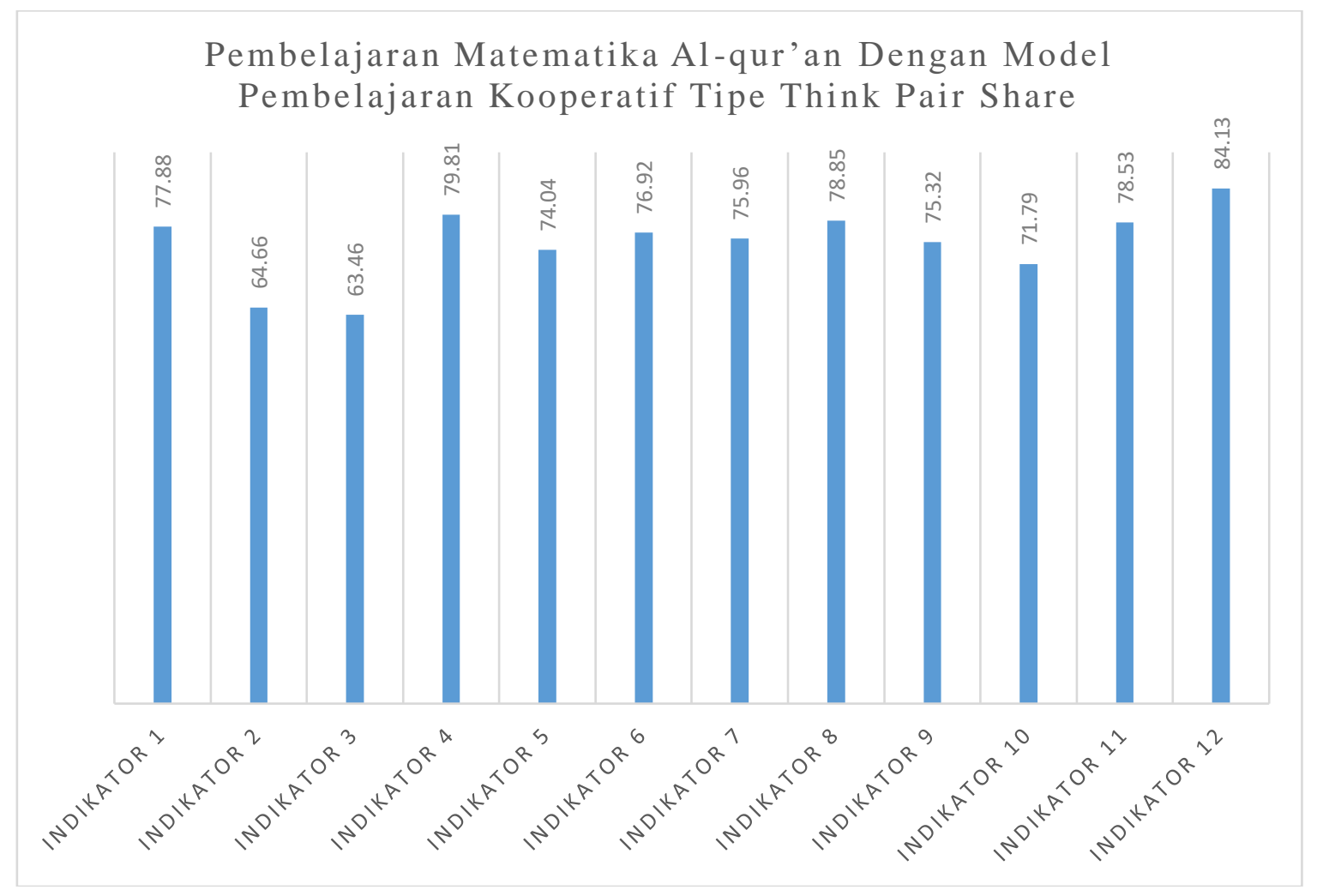

Gambar 1 Rekapitulasi Persentase Rata-rata Hasil Angket Respon Siswa

Selanjutnya sebelum tes dilaksanakan, terlebih dahulu dilakukan uji coba instrumen di kelas VIII A sebanyak 10 butir soal. Setelah dilakukan uji coba instrumen. Selanjutnya dilakukan uji validitas, uji reliabilitas, uji taraf kesukaran dan uji daya pembeda butir soalnya. Berdasarkan hasil perhitungan diperoleh semua soal valid dengan reliabilitas 0,42 .

Adapun data hasil posttest persentase rata-rata tiap indikator pada kemampuan komunikasi matematis siswa antara kelas eksperimen dan kelas kontrol. Kelas eksperimen pada indikator sudah mampu menghubungkan benda nyata, gambar, dan diagram kedalam ide matematika memperoleh hasil persentase $80,38 \%$. Indikator menjelaskan ide, situasi, dan relasi matematika secara lisan atau tulisan dengan benda nyata, gambar, grafik, dan aljabar memperoleh hasil persentase $75,51 \%$. Indikator menyatakan peristiwa sehari-hari dalam bahasa matematika memperoleh hasil persentase $81,54 \%$ yang merupakan indikator tertinggi. Indikator mendengarkan, diskusi, dan menuliskan tentang matematika memperoleh hasil persentase $79,23 \%$. Indikator membaca dengan pemahaman suatu presentasi matematika tertulis memperoleh hasil persentase $74,62 \%$ yang merupakan indikator terrendah. Indikator menjelaskan dan menyusun pertanyaan matematika yang relevan dengan situasi masalah memperoleh hasil persentase 76,92\%. Dan indikator membuat konjektur, menyusun argumen, merumuskan definisi dan generalisasi memperoleh hasil persentase 76,35\%.

Sedangkan pada kelas kontrol dari indikator menghubungkan benda nyata, gambar, dan diagram kedalam ide matematika memperoleh hasil persentase $72,31 \%$ yang merupakan indikator tertinggi. Indikator menjelaskan ide, situasi, dan relasi matematika secara lisan atau tulisan dengan benda nyata, gambar, grafik, dan aljabar memperoleh hasil persentase $60,38 \%$. Indikator menyatakan peristiwa sehari-hari dalam bahasa matematika memperoleh hasil persentase $63,46 \%$. Indikator mendengarkan, diskusi, dan menuliskan tentang matematika memperoleh hasil persentase $71,54 \%$. Indikator membaca dengan pemahaman suatu presentasi matematika tertulis memperoleh hasil persentase $63,59 \%$ yang merupakan indikator terrendah. Indikator menjelaskan dan menyusun pertanyaan matematika yang relevan dengan situasi masalah memperoleh hasil persentase 61,54\%. Dan indikator membuat konjektur, menyusun argumen, merumuskan definisi dan generalisasi memperoleh hasil persentase $67,69 \%$. Adapun untuk hasil posttest kemampuan komunikasi matematis siswa lebih jelasnya dapat dilihat pada Tabel 2 sebagai berikut: 


\begin{tabular}{|c|c|c|c|}
\hline \multirow[b]{2}{*}{ No. } & \multirow[b]{2}{*}{ Indikator Kemampuan Komunikasi Matematis Siswa } & \multicolumn{2}{|c|}{ Rata-rata Skor (\%) } \\
\hline & & $\begin{array}{c}\text { Kelas } \\
\text { Eksperimen }\end{array}$ & $\begin{array}{l}\text { Kelas } \\
\text { Kontrol }\end{array}$ \\
\hline 1 & $\begin{array}{c}\text { Menghubungkan benda nyata, gambar, dan diagram kedalam } \\
\text { ide matematika. }\end{array}$ & $80,38 \%$ & $72,31 \%$ \\
\hline 2 & $\begin{array}{l}\text { Menjelaskan ide, situasi, dan relasi matematika secara lisan } \\
\text { atau tulisan dengan benda nyata, gambar, grafik, dan aljabar. }\end{array}$ & $75,51 \%$ & $60,38 \%$ \\
\hline 3 & Menyatakan peristiwa sehari-hari dalam bahasa matematika. & $81,54 \%$ & $63,46 \%$ \\
\hline 4 & $\begin{array}{l}\text { Mendengarkan, diskusi, dan menuliskan tentang } \\
\text { matematika. }\end{array}$ & $79,23 \%$ & $71,54 \%$ \\
\hline 5 & $\begin{array}{c}\text { Membaca dengan pemahaman suatu presentasi matematika } \\
\text { tertulis. }\end{array}$ & $74,62 \%$ & $63,59 \%$ \\
\hline 6 & $\begin{array}{c}\text { Menjelaskan dan menyusun pertanyaan matematika yang } \\
\text { relevan dengan situasi masalah. }\end{array}$ & $76,92 \%$ & $61,54 \%$ \\
\hline 7 & $\begin{array}{l}\text { Membuat konjektur, menyusun argumen, merumuskan } \\
\text { definisi dan generalisasi. }\end{array}$ & $76,35 \%$ & $67,69 \%$ \\
\hline & Rata-rata & $77,79 \%$ & $65,79 \%$ \\
\hline
\end{tabular}

Berdasarkan Tabel 2 penjelasan dapat dilihat bahwa hasil persentase rata-rata posttest kemampuan komunikasi matematis siswa kelas eksperimen pada indikator menyatakan peristiwa sehari-hari dalam bahasa matematika merupakan hasil persentase tertinggi diantara indikator lainnya, hal ini berarti kemampuan siswa dalam menyatakan peristiwa sehari-hari dalam bahasa matematika sudah meningkat. Sedangkan kelas kontrol pada indikator menghubungkan benda nyata, gambar, dan diagram kedalam ide matematika merupakan hasil tertingginya, hal ini berarti dalam kelas kontrol pada kemampuan siswa dalam menghubungkan benda nyata, gambar, dan diagram kedalam ide matematika sudah meningkat juga. Hasil persentase rata-rata tiap indikator kemampuan komunikasi matematis siswa kelas eksperimen sebesar 77,79\% dan kelas kontrol sebesar $65,79 \%$. Dengan demikian hasil persentase rata-rata tiap indikator berada diatas skor minimal yaitu 50\%, maka siswa kelas eksperimen sudah dikatakan mempunyai kemampuan komunikasi matematis siswa yang lebih meningkat daripada kelas kontrol.

Hasil persentase rata-rata dari tabel diatas menunjukan bahwa antara kelas eksperimen dan kelas kontrol terdapat perbedaan, karena kelas eksperimen diberi perlakukan pembelajaran matematika Al-Qur'an dengan model pembelajaran kooperatif tipe Think Pair Share, sedangkan kelas kontrol dalam proses pembelajaran tidak diberikan perlakuan atau menggunakan metode konvensional. Untuk lebih jelasnya hasil posttest kemampuan komunikasi matematis siswa dengan persentase rata-rata antara kelas eksperimen dan kelas kontrol dapat disajikan pada Gambar 2 sebagai berikut:

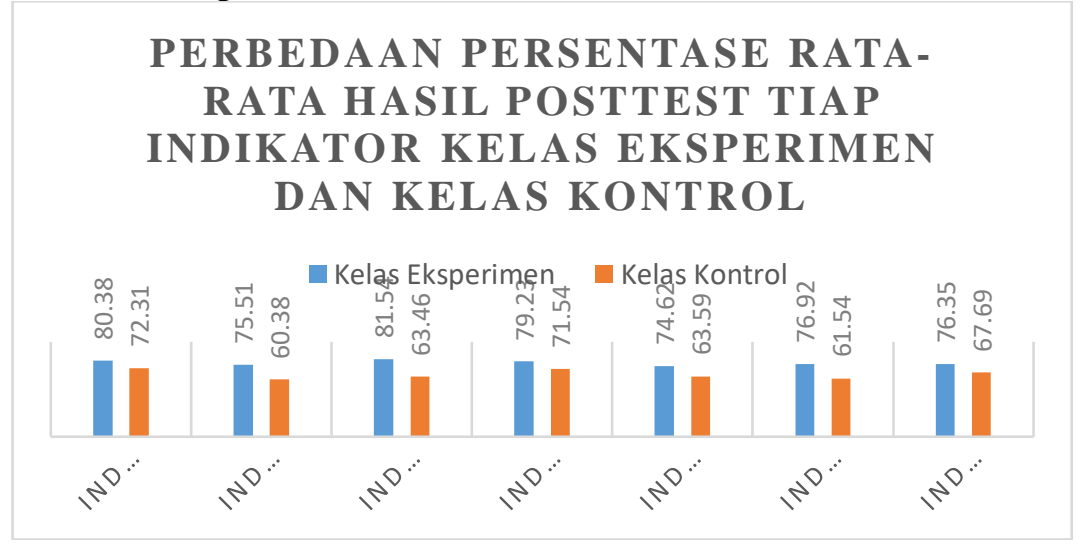

Gambar 2 Perbedaan Hasil Posttest Kelas Eksperimen dan Kelas Kontrol 
Setelah diperoleh hasil data posttest kemampuan komunikasi matematis siswa, kemudian dilakukan uji analisis data, dapat dilihat pada penjelasan sebagai berikut:

Uji Prasyarat Analisis Data

Uji Normalitas

Uji normalitas dilakukan untuk mengetahui apakah sampel yang akan diteliti berasal dari distribusi normal atau tidak. Sebelum melakukan analisis data sesungguhnya, maka data tersebut harus melalui uji prasyarat terlebih dahulu akan diuji kenormalitasan distribusinya. Hal ini sangat penting kita ketahui karena keterkaitan dengan ketepatan pemilihan uji statistik yang akan digunakannya. Adapun perumusan hipotesis pengujian normalitas adalah sebagai berikut:
$H_{0}=$ data berdistribusi normal

$H_{1}=$ data tidak berdistribusi normal

dengan kriteria pengujian hipotesis sebagai berikut:

Jika nilai /P-value/ Sig. > 0,05, maka $H_{0}$ diterima.

Jika nilai /P-value/ Sig. $\leq 0,05$, maka $H_{0}$ ditolak.

Untuk perhitungan uji normalitas data dalam penelitian ini, maka peneliti akan menggunakan uji Shapiro-Wilk dengan bantuan software SPSS version 25 dengan memperoleh hasil output dapat dilihat pada Tabel 3 sebagai berikut:

\begin{tabular}{|c|c|c|c|c|c|c|c|}
\hline \multirow{2}{*}{} & \multirow{2}{*}{ Kelas } & \multicolumn{2}{|c|}{ Kolmogorov-Smirnov ${ }^{\mathrm{a}}$} & \multicolumn{3}{|c|}{ Shapiro-Wilk } \\
\cline { 3 - 8 } & Statistic & df & Sig. & Statistic & df & Sig. \\
\hline \multirow{2}{*}{$\begin{array}{c}\text { Kemampuan } \\
\text { Komunikasi } \\
\text { Matematis Siswa }\end{array}$} & Kontrol & 0,121 & 26 & $0,200^{*}$ & 0,935 & 26 & 0,101 \\
\cline { 3 - 8 } & Eksperimen & 0,136 & 26 & $0,200^{*}$ & 0,960 & 26 & 0,396 \\
\hline
\end{tabular}

Berdasarkan Tabel 3 diatas, hasil output untuk uji normalitas data dengan menggunakan uji Shapiro-Wilk diperoleh nilai sig. 0,396 untuk kelas eksperimen, sedangkan kelas kontrol nilai sig. 0,101 . Nilai tersebut lebih besar dari $\propto=$ 0,05 , karena nilai sig. $>0,05$ maka $H_{0}$ diterima. Maka dapat disimpulkan bahwa data tersebut berdistribusi normal.

Uji Homogenitas

Uji homogenitas dilakukan untuk mengetahui apakah varians dari kedua kelompok sampel yang dianalisis berasal dari populasi yang sama (homogen) atau yang berbeda (heterogen). Adapun perumusan hipotesis pengujian homogenitas pada penelitian ini adalah sebagai berikut:

$H_{0}=$ kedua varians homogen

$H_{1}=$ kedua varians tidak homogen

dengan kriteria pengujian hipotesis sebagai berikut:

Jika nilai /P-value/ Sig. $>0,05$, maka $H_{0}$ diterima, yaitu berdistribusi homogen.

Jika nilai /P-value/ Sig. $\leq 0,05$, maka $H_{0}$ ditolak, yaitu berdistribusi tidak homogen.

Adapun untuk mengetahui data tersebut hasilnya homogen atau tidak, peneliti menggunakan bantuan software SPSS version 25 dengan hasil output dapat dilihat pada Tabel 4 sebagai berikut:

Tabel 4 Test of Homogenity of Variances

\begin{tabular}{|c|c|c|c|c|c|}
\hline \multicolumn{2}{|c|}{} & $\begin{array}{c}\text { Levene } \\
\text { Statistic }\end{array}$ & df1 & df2 & Sig. \\
\hline \multirow{2}{*}{$\begin{array}{c}\text { Kemampuan } \\
\text { Komunikasi } \\
\text { Matematis Siswa }\end{array}$} & Based on Mean & 5,876 & 1 & 50 & 0,019 \\
\cline { 2 - 6 } & Based on Median & 4,886 & 1 & 50 & 0,032 \\
\cline { 2 - 6 } & $\begin{array}{c}\text { Based on Median and with } \\
\text { adjusted df }\end{array}$ & 4,886 & 1 & 39,866 & 0,033 \\
\cline { 2 - 7 } & Based on trimmed mean & 5,732 & 1 & 50 & 0,020 \\
\hline
\end{tabular}


Berdasarkan Tabel 4 diatas, hasil output untuk uji homogenitas dari Based on Mean diperoleh nilai sig. 0,019. nilai tersebut lebih kecil dari nilai $\propto=0,05$, karena nilai sig. $\leq 0,05$ maka $H_{0}$ ditolak. Maka dapat disimpulkan bahwa data tersebut berdistribusi tidak homogen.

Uji Hipotesis

Uji hipotesis dilakukan untuk mengetahui apakah hipotesis yang diajukan diterima atau ditolak. Maka dari hasil perhitungan uji prasyarat analisis data menunjukan bahwa hasil data tes kemampuan komunikasi matematis siswa pada kelas eksperimen dan kelas kontrol berdistribusi normal namun tidak homogen. Dengan demikian, selanjutnya akan dilakukan uji hipotesis dengan menggunakan uji t' (t aksen). Jika terdapat perbedaan yang signifikan antara kelompok eksperimen dan kelompok kontrol, maka proses perlakuan yang diberikan peneliti berpengaruh positif untuk pengujian hipotesis. Adapun perumusan hipotesis pengujian tersebut berlaku ketentuan sebagai berikut:

$H_{0}: \mu_{1}=\mu_{2}$ tidak terdapat perbedaan rata-rata kemampuan komunikasi matematis siswa pada kelas eksperimen dibandingkan dengan siswa pada kelas kontrol.

$H_{1}: \mu_{1} \neq \mu_{2}$ terdapat perbedaan rata-rata kemampuan komunikasi matematis siswa pada kelas eksperimen dan siswa pada kelas kontrol.

Keterangan:

$\mu_{1}=$ skor rata-rata hasil tes kemampuan komunikasi matematis siswa pada kelas eksperimen

$\mu_{2}=$ skor rata-rata hasil tes kemampuan komunikasi matematis siswa pada kelas kontrol

dengan kriteria pengujian hipotesis sebagai berikut:

Jika nilai $t_{\text {hitung }}<t_{\text {tabel }}$, maka $H_{0}$ diterima artinya tidak terdapat perbedaan antara $\mu_{1}$ dan $\mu_{2}$

Jika nilai $t_{\text {hitung }}>t_{\text {tabel }}$, maka $H_{0}$ ditolak artinya terdapat perbedaan antara $\mu_{1}$ dan $\mu_{2}$.

Adapun hasil perhitungan uji hipotesis dengan rumus uji t' ( $\mathrm{t}$ aksen) menggunakan bantuan Aplikasi Microsoft Excel dapat disajikan pada 
Jurnal Riset Pendidikan Matematika Jakarta 2020; 2 (2): 1-12

Tabel 5 sebagai berikut:

Tabel 5 Hasil Uji Hipotesis

\begin{tabular}{|c|c|c|c|c|c|c|c|}
\hline Kelompok & $\mathrm{N}$ & $\begin{array}{c}\text { Rata- } \\
\text { rata }\end{array}$ & $\begin{array}{c}\text { Simpangan } \\
\text { baku }\end{array}$ & Varians & t hitung & $\mathrm{t}$ tabel & Kesimpulan \\
\cline { 1 - 5 } Eksperimen & 26 & 76,96 & 12,635 & 159,638 & \multirow{2}{*}{34,365} & $-1,706$ & $H_{0}$ diterima. \\
\hline Kontrol & 26 & 64,50 & 8,006 & 64,100 & & \\
\hline
\end{tabular}


Berdasarkan

Tabel 5 diatas dari hasil perhitungan analisis uji t' (t aksen) dapat diketahui bahwa nilai ratarata dari kelas eksperimen adalah 76,96 dan nilai rata-rata dari kelas kontrol adalah 64,50. Dengan nilai varians dari kelas eksperimen adalah 159,638 dan kelas kontrol adalah 64,100. Selanjutnya akan diuji t, dimana pada tabel diatas dapat kita lihat bahwa t-hitung 34,365 dan t-tabel -1,706. Maka dapat disimpulkan bahwa t-hitung $>$ t-tabel yaitu 34,365 > -1,706. Hal ini berarti bahwa pada hipotesis penelitiannya adalah
$H_{0}$ diterima. Dengan kata lain bahwa terdapat pengaruh pembelajaran matematika al-qur'an dengan model pembelajaran kooperatif tipe think pair share terhadap kemampuan komunikasi matematis siswa pada pokok bahasan garis dan sudut dikelas VII MTsNU Astanajapura Tahun Ajaran 2019/2020. Dan hal ini berarti bahwa terdapat perbedaan tingkat kemampuan komunikasi matematis siswa yang diajarkan dikelas eksperimen dan kelas kontrol.

\section{SIMPULAN}

Berdasarkan hasil penelitian, pembahasan dan kajian teori maka dalam penelitian ini dapat disimpulkan sebagai berikut: (1) Respon siswa terhadap pembelajaran matematika al-qur'an dengan model pembelajaran think pair share dalam proses kegiatan pembelajaran dapat diketahui dari siswa dengan diperoleh persentase rata-rata hasil angket respon siswa sebesar $75,11 \%$ maka kategori kuat. Hal ini berarti siswa merespon positif terhadap pembelajaran matematika al-qur'an dengan model pembelajaran think pair share dalam kegiatan pembelajaran. (2) Hasil kemampuan komunikasi matematis siswa pada kelas eksperimen yang menerapkan pembelajaran matematika al-qur'an dengan model pembelajaran think pair share memperoleh persentase rata-rata sebesar 77,79\% maka termasuk kategori baik. Hal ini berarti menunjukan bahwa pada kemampuan komunikasi matematis siswa setelah diterapkan pembelajaran matematika al-qur'an dengan model pembelajaran think pair share ini meningkat dengan baik. (3) Pengaruh pembelajaran matematika al-qur'an dengan model pembelajaran think pair share terhadap kemampuan komunikasi matematis siswa dapat dilihat dari hasil Uji linieritas kedua kelas ekperimen dan kontrol didapatkan nilai sig 0,004 karena $0,004<0,05$ maka antara variabel respon siswa penerapan pembelajaran matematika al-qur'an dengan model pembelajaran think pair share terhadap kemampuan komunikasi matematis siswa terdapat hubungan linier. Untuk analisis korelasi (hubungan) didapatkan nilai $\mathrm{r}$ hitung adalah 0,343 . Karena nilai $r$ hitung $>r$ tabel yaitu 0,343 $>0,330$ maka ada hubungan signifikan antara pembelajaran matematika al-qur'an dengan model pembelajaran think pair share terhadap kemampuan komunikasi matematis siswa. Dalam uji regresi memiliki pengaruh $11,8 \%$, diperoleh persamaan regresi $Y=125,122+0,647 X$, dan nilai signifikasi adalah 0,004 karena $0,004<0,05$, dari kedua pernyataan tersebut maka terjadi hubungan linier antara pembelajaran matematika al-qur'an dengan model pembelajaran think pair share terhadap kemampuan komunikasi matematis siswa. Hal ini terlihat dari nilai t-hitung yaitu 34,365 lebih besar dibandingkan dengan nilai t-tabel yaitu $-1,706$ itu artinya t-hitung > t-tabel maka Ho diterima. Dengan demikian bahwa terdapat pengaruh yang signifikan pembelajaran matematika al-qur'an dengan model pembelajaran think pair share terhadap kemampuan komunikasi matematis siswa.

\section{UCAPAN TERIMA KASIH}

Terimakasih banyak kepada dosen pembimbing skripsi, dosen pembimbing akademik, dosen dan staff matematika, keluarga besar, temen seperjuangan, sahabat, dan semuanya yang tak bisa disebutkan satu persatu atas dedikasi, support, doanya. Semoga ini bisa bermanfaat bagi semuanya.

\section{SARAN}


Penulis berharap agar para peneliti atau calon peneliti yang akan datang dapat meneruskan atau mengembangkan penelitian dengan salah satunya menggunakan pembelajaran matematika alqur'an dengan model pembelajaran think pair share sehingga mampu memberikan peningkatan yang lebih baik lagi. Selain itu, sebaiknya lebih ditekankan lagi pada proses think dan masalah yang diajukan yaitu masalah kontekstual agar lebih mudah dipahami. Selanjutnya, sebaiknya sebelum proses pembelajaran ini dipersiapkan dan direncanakan terlebih dahulu dengan cermat, memperhatikan faktor-faktor yang memengaruhi dalam proses pembelajaran, diharapkan menggembangkan model pembelajaran Think Pair Share dengan aspek penelitian yang lain pada kajian yang lebih luas. Bagi siswa, diharapkan untuk lebih fokus dalam kegiatan belajar dan hendaknya mengikuti segala apa yang disampaikan guru, sehingga dapat terlaksana kompetensi yang ingin dicapai salah satunya kemampuan komunikasi matematis yang lebih baik lagi.

Bagi guru, dalam penggunaan model pembelajaran diharapkan agar memperhatikan faktor-faktor, kelebihan, dan kekurangan serta perkembangan kognitif siswa, sehingga kegiatan belajar akan berjalan dengan lebih baik dan kemampuan komunikasi matematis dapat dikembangkan lagi secara maksimal.

Bagi sekolah, pembelajaran matematika AlQur'an dengan model pembelajaran kooperatif tipe Think Pair Share ini mampu meningkatkan kemampuan komunikasi matematis siswa, sehingga dapat dijadikan sebagai salah satu alternatif dalam pembelajaran matematika yang lebih inovatif.

\section{DAFTAR PUSTAKA}

Abdussyakir. (2007). Ketika Kiyai Mengajar Matematika. Malang: UIN-Maliki Press.

Arikunto, S. (2018). Dasar-Dasar Evaluasi Pendidikan. Jakarta: Bumi Aksara.

Fathoni, A. H. (2012). Matematika Hakikat dan Logika. Yogyakarta: Ar-Ruzz.

Izzati, N. (2014, Juni). Pengaruh Keterampilan Sosial Terhadap Kemampuan Komunikasi Matematis Mahasiswa. Jurnal Edueksos, III, 87-100.

Izzati, N. (2017). Peningkatan Kemampuan Analisis Matematis Mahasiswa melalui Penerapan Pendekatan Open-Ended. Jurnal THEOREMS (The Original Research of Mathematics), 72-81.

Lestari, K. E., \& Yudhanegara, M. R. (2017). Penelitian Pendidikan Matematika. Bandung: PT Refika Aditama.

Maksudin. (2015). Desain Pengembangan Berfikir Integratif-Interkonektif Pendidikan Dialektik. Yogyakarta: Pustaka Pelajar.

Mulyatiningsih, E. (2014). Metode Penelitian Terapan Bidang Pendidikan. Bandung: Alfabeta.

NCTM. (2000). Principles and Standards for School Mathematics. Reston: NCTM.
Nursuprianah, I. (2017). Pemodelan Matematika Manfaat Jumlah Rakaat Sholat pada Pembakaran Kalori dalam Tubuh. Jurnal EduMa, 1-8.

Nursuprianah, I. (2017). Pemodelan Matematika Rentang Waktu yang Dibutuhkan dalam Menghafal Al-Qur'an. Jurnal THEOREMS (The Original Research of Mathematics), 110.

Riduwan. (2011). Metodologi Penelitian. Bandung: Alfabeta.

Sugiyono. (2016). Metode Penelitian Pendidikan. Bandung: Alfabeta.

Sugiyono. (2018). Metode Penelitian Pendidikan (Pendekatan Kuantitatif, Kualitatif dan R\&D). Bandung: Alfabeta.

Suherman, E. (2013). Strategi Pembelajaran Matematika Kontemporer. Bandung: JICA. 